\title{
Pengaruh Kegiatan Bermain Congklak Terhadap Kemampuan Kognitif Anak Usia 4-5 Tahun Di TK An-Nur
}

\author{
Received : 17 September 2020 Revised : 20 November 2020
}

Accepted : 24 November 2020

\author{
Nursyah Rida Syanti Siregar ${ }^{1}$, Dorlince Simatupang ${ }^{2}$ \\ Fakultas Ilmu Pendidikan \\ Universitas Negeri Medan \\ Jln. Willem Iskandar Psr V Medan Estate \\ E-mail : nursyahridasyanti@gmail.com
}

\begin{abstract}
Abstrak. Permasalahan pada penelitian ini adalah kemampuan kognitif anak masih rendah, pembelajaran yang dilakukan guru kurang menarik. Penelitian ini bertujuan untuk mengetahui Pengaruh permainan congklak terhadap kemampuan kognitif anak pada usia 4-5 tahun di TK AN NUR Jenis penelitian ini adalah kuantitatif dengan metode eksperimen menggunakan desain Possstest-Only Control design. Populasi dalam penelitian ini adalah seluruh anak kelompok A usia 4-5 tahun di TK AN NUR. Sampel dalam penelitian ini yaitu kelas B1 sebagai kelas eksperimen dan kelas B2 sebagai kelas kontrol. Teknik pengumpulan data menggunakan observasi. Pengujian ini digunakan dengan menggunakan uji Liliefors (uji-t) dengan taraf nyata $=\nmid 0,05$. Hasil penelitian menunjukkan bahwa ada perbedaan yang sifgnifikan. Setelah dilakukan perlakuan yang berbeda diperoleh rata-rata skor kemampuan kognitif anak kelas ekperimen 6,25 dan kelas kontrol 4,37 . dari hasil observasi kedua sampel diperoleh selisih 1,88. Dari data yang diperoleh tersebut didapat perbedaan yang signifikan antara kemampuan kognitif anak dikelas ekperimen dan kelas kontrol.
\end{abstract}

Sedangkan hasil uji hipotesis terbukti bahwa toelyง $\square(0,8065)>$ tlæą̧ $(0,285)$. Hal tersebut sesuai dengan hasil uji hipotesis $\mathrm{H} \square$ ditolak dan Hœ diterima. Sehingga dapat dinyatakan ada pengaruh yang signifikan permainan congklak terhadap kemampuan kognitif anak usia 4-5 tahun di TK AN NUR

Kata Kunci: bermain congklak, kemampuan kognitif anak

\section{PENDAHULUAN}

Kemampuan kognitif merupakan suatu proses dan produk pikiran untuk mencapai pengetahuan berupa aktivitas mental seperti mengingat, menyimbolkan, mengkategorikan, memecahkan masalah, menciptakan dan berfantasi.

Menurut Witherington ( dalam susanto $2011: 15$ ) menyatakan bahwa kemampuan kognitif adalah " pikiran, melalui pikiran dapat digunakan dengan cepat dan tepat untuk mengatasi suatu situasi untuk memecahkan masalah ".

Sedangkan menurut putjiati ( dalam Khadijah 2016 : 31 ) bahwa kognitif dapat diartikan dengan kemampuan belajar atau berfikir atau kecedasan yaitu kemampuan untuk mempelajari keterampilan dan konsep baru, keterampilan untuk memahami apa yang terjadi dilingkungannya, serta keterampilan menggunakandaya ingat dan menyelesaikan soal-soal sederhana 
Menurut Susanto (2011 : 98) menyatakan bahwa, "kemampuan berhitung permulaan ialah kemampuan yang dimiliki setiap anak untuk mengembangkan kemampuannya, karakteristik perkembangan dimulai dari lingkungan yang terdekatdengan dirinya, sejalan dengan perkembangan dan kemampuan anak dapat meningkat terhadap pengertian mengenai jumlah, yaitu berhubungan dengan jumlah dan pengurangan. Dalam kaitan ini bahwa salah satu cabang matematika adalah berhitung merupakan dasar dari beberapa ilmu yang dipakai dalam setiap kehidupa manusia.

Berhitung merupakan bagian dari matematika, diperlukan untuk menumbuh kembangkan keterampilan berhitung yang sangat diperlukan dalam kehidupan sehari-hari, terutama konsep bilangan yang merupakan juga dasar bagi pengembangan kemampuan matematika maupun kesiapan untuk mengikuti pendidikan dasar. Menurut Susanto (dalam Khadijah 2016:143) kemampuan berhitung permulaan adalah kemampuan yang dimiliki setiap anak untuk mengembangkan kemampuannya. Karakteristik perkembangannya dimulai dari lingkungan yang terdekat dengan dirinya, sejalan dengan perkembangan kemampuannya anak dapat meningkat ketahap pengertian mengenai jumlah, yang berhubungan dengan penjumlahan dan pengurangan. Berhitung permulaan merupakan bagian dari matematika, diperlukan dalam kehidupan sehari-hari, terutama konsep bilangan yang merupakan juga dasar bagi pengembangan kemampuan matematika guna kesiapan untuk mengikuti pendidikan dasar. Bagi anak usia dini, kemampuan tersebut disebut dengan kemampuan berhitung permulaan.

Mengingat begitu pentingnya kemampuan berhitung bagi manusia, maka kemampuan berhitung ini perlu diajarkan sejak usia dini, dengan berbagai media dan metode yang tepat jangan sampai merusak pola perkembangan anak.

Dalam pelaksanaan pembelajaran untuk mengembangkan berbagai kecerdasan semua saling terkait dan saling mendukung, karena pembelajaran anak usia dini adalah pembelajaran terpadu. Pembelajaran pada anak usia dini dapat dilakukan dengan cara bermain yang disesuaikan dengan tahap-tahap perkembangan anak. karena anak dalam usia dini membutuhkan banyak rangsangan yang akan diperoleh melalui bermain.

Bermain juga merupakan proses alamiah dan naluriah yang sangat baik bagi kesehatan fisik dan psikis anak dalam masa perkembangannya. Dengan bermain anak bisa merasa bahagia. Rasa bahagia inilah yang menstimulasi saraf-saraf otak anak untuk saling terhubung sehingga membentuk sebuah memori yang indah akan membuat jiwanya sehat.

Menurut Subagiyo (dalam Mulyani 2016:51)menyatakan bahwa manfaat permainan tradisional yaitu, mengembangkan kecerdasan logika anak, beberapa permainan tradisional melatih anak untuk berhitung dan menentukan langkah-langkah yang harus dilewati. Misalnya engklek, congklak lompat tali,encrak,bola bekel, dan lain-lain. Kegiatan yang dapat mengembangkan kemampuan kognitif anak (menghitung permulaan) salah satu dengan permainan congklak.

Pada waktu melakukan observasi awal di TK AN-NUR kenyataan kemampuan kognitif anak (menghitung permulaan) masih kurang. Dapat dilihat dalam proses pembelajaran anak-anak belum mampumenghitung angka 1 s/d 10.6 dari 8 anak atau $75 \%$ belum bisamenghitung $1 \mathrm{~s} / \mathrm{d} 10$, sedangkan 2 dari 8 orang atau $25 \%$ sudah bisamenghitung angka $1 \mathrm{~s} / \mathrm{d}$ 10. Peristiwa ini kemungkinan juga dipengaruhi oleh guru yang lebih sering menggunakan media gambar, buku dan terkadang hanya menggunakan metode ceramah 
dalam menyampaikan materi berhitung. Sehingga anak kurang merespon terhadap apa yang disampaikan oleh guru. Karena media yang digunakan kurang menarik maka peserta didik menjadi bosan dengan media yang digunakan. Mereka sering bermain-main atau malah bicara dengan temannya. Pada akhirnya saat disuruh untuk mengerjakan tugas mereka menjadi bingung.

Haris arifah (2014) mengatakan bahwa ada pengaruh antara permainan congklak terhadap kemampuan kognitif anak. Anak yang menggunakan permainan congklak dapat lebih mudah dan lebih faham dalam menghitung. Dengan adanyapermainan congklak dapat dinilai meningkatkan kemampuan berhitung permulaan anak. permainan congklak juga membuatanak lebih mudah memahami materi pembelajaran.

Deska Alvisari (2017 ) Mengatakan bahwa ada pengaruh antara permainan congklak terhadap kemampuan kognitif anak. Dapat dilihat setelah bermain anak dapat menghitung biji congklak yang didapatkan, mengurutkan banyak dan sedikit dan mencocokkan bilangan dengan lambang bilangan dan menggunakan lambang bilangan untuk menghitung.

Dari uraian penelitian diatas dapat disimpulkan bahwa ada pengaruh antara permainan congklak terhadap kemampuan kognitif anak. Karena dengan bermain congklak anak dapat menghitung biji congklak mengurutkan biji congklak yang sedikit hingga biji congklak yang banyak.

Pada penelitian ini, peneliti menggunakan permainan sebagai usaha untuk meningkatkan kemampuan kognitif (menghitung permulaan) anak di TK AN-NUR. Peneliti menginginkan adanya perubahan dalam proses pembelajaran, karena dengan bermain congklak dapat meningkatkan kemampuan kognitif (menghitung permulaan) anak.Dengan itu peneliti tertarik membuat pembelajaran dengan belajar sambil bermain. Selain itu peneliti berharap dengan belajar sambil bermain sebagai alat bantu dalam proses pembelajaran dapat berlangsung efektif, menyenangkan dan dapat meningkatkan anak sehingga kemampuan kognitif (menghitung permulaan)anak dapat berkembang sesuai dengan karakteristiknya

\section{METODOLOGI PENELITIAN}

Jenis penelitian yang digunakan dalam penelitian ini adalah Penelitian Ekperimen. Desain dalam penelitian ini adalah True Eperimental Design, dikatakan true ekperimental karena ekperimen yang betul-betul .karena dalam desain ini peneliti dapat mengontrol semua variabel luar yang mempengaruhi jalannya eksperimen., dengan bentuk Possstest-Only Control design dalam metode ini terdapat kelompok Ekperimen dan kelompok Kontrol yang dipilih secara random.

Teknik pengumpulan data dalam penelitian ini menggunakan instrumental non tes yaitu observasi terstruktur tentang kemampuan kognitif (berhitung permulaan) anak.Observasi ini menggunakan pedoman observasi yang berisi sebuah daftar. jenis penelitian atau perilaku yang mungkin timbul danakan diamati. Penataan data dilakukan dengan memuat nama observer. 
Tabel 1. Kisi-kisi Penilaian Kemampuan kognitif ( berhitung permulaan)

\begin{tabular}{|c|c|c|}
\hline Variabel & Indikator & Deskriptor \\
\hline \multirow{9}{*}{$\begin{array}{l}\text { Kemampuan } \\
\text { kognitif } \\
\text { (berhitung } \\
\text { permulaan) } \\
\text { usia 4-5 } \\
\text { tahun }\end{array}$} & \multirow{3}{*}{$\begin{array}{l}\text { Mengurutkan } \\
\text { urutan } \\
\text { bilangan 1-10 }\end{array}$} & 1. anak belum mampu mengurutkan angka 1-10 \\
\hline & & 2. anak mulai mampumengurutkan angka 1-10 \\
\hline & & 3. anak mampu mengurutkan angka $1-10$ \\
\hline & \multirow{3}{*}{$\begin{array}{l}\text { Menghubungk } \\
\text { an/memasangk } \\
\text { an } \\
\text { Dengan benda- } \\
\text { benda } 1-10\end{array}$} & $\begin{array}{l}\text { 1. anak belum mampu memasangkan biji } \\
\text { congklak pada papan congklak dengan jumlah } \\
\text { yang benar }\end{array}$ \\
\hline & & $\begin{array}{l}\text { 2. anak sudah mulai mampu memasangkanbiji } \\
\text { congklak pada papan congklak dengan jumlah } \\
\text { yang benar }\end{array}$ \\
\hline & & $\begin{array}{l}\text { 3. anak mampu memasangkan biji congklak pada } \\
\text { papan congklak dengan jumlah yang benar }\end{array}$ \\
\hline & \multirow{3}{*}{$\begin{array}{l}\text { Menyebutkan } \\
\text { hasil } \\
\text { penambahan } \\
\text { dengan benda } \\
1-10\end{array}$} & $\begin{array}{l}\text { 1. anak belum mampu menyebutkan hasil } \\
\text { penambahan biji congklak 1-5. }\end{array}$ \\
\hline & & $\begin{array}{l}\text { 2. Anak menyebutkan menyebutkan hasil } \\
\text { penambahan biji congklak 1-7. }\end{array}$ \\
\hline & & $\begin{array}{l}\text { 3. anak mampu menyebutkan hasil penambahan } \\
\text { biji congklak } 1-10\end{array}$ \\
\hline
\end{tabular}

Keterangan:

Sumber : Sri Ningsih, (Khadijah 2016:144)

karakteristik kemampuan berhitung permulaan anak usia 4-5 tahun

Observasi selama 4 kali : Nilai 3 : Jika diskriptor 3 teramati

Nilai 2 : Jika diskriptor 2 teramati

Nilai 1 : Jika diskriptor 1 teramati

\section{HASIL DAN DISKUSI}

Dalam bab III peneliti telah menjelaskan bahwa teknik pengumpulan data pada penelitian ini menggunakan teknik observasi dengan melibatkan dua kelas yang diberikan perlakuan yang berbeda, yaitu kelas eksperimen dengan menggunakan permainan congklak dan kelas control dengan menggunakan permainan ular naga. Lembar observasi yang dibutuhkan telah disusun sedemikian rupa sehingga dapat digunakan untuk melihat perkembangan kemampuan kognitif anak.

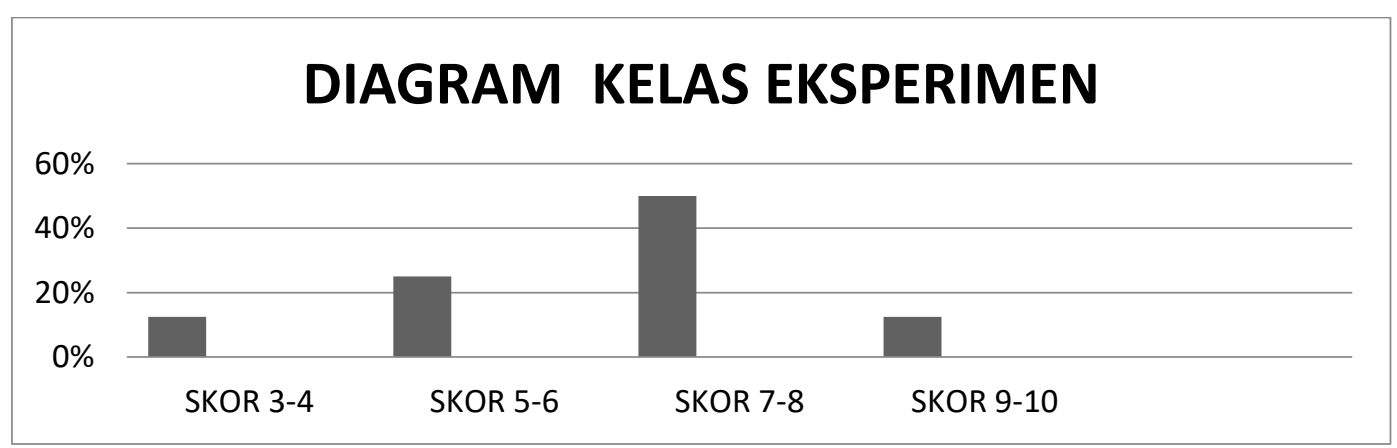

Gambar 1. Distribusi Frekuensi Data Hasil Observasi Kemampuan Kognitif Anak Kelas Eksperimen 


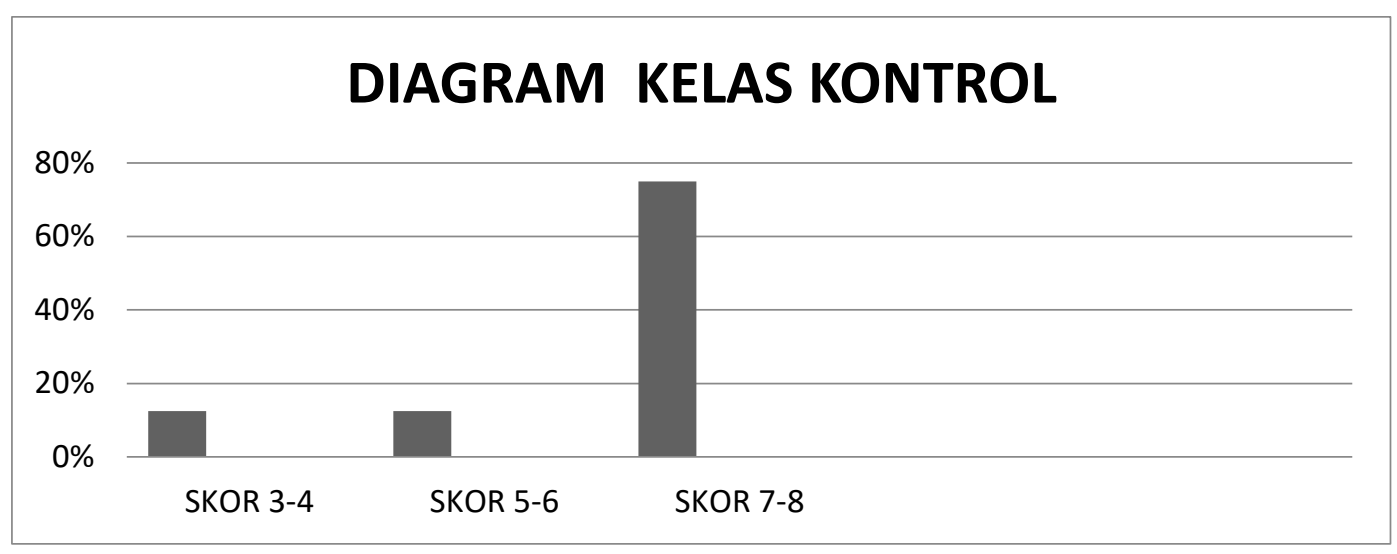

Gambar 2. Distribusi Frekuensi Data Hasil Observasi Kemampuan Kognitif Anak Kelas Kontrol

Berdasarkan data hasil observasi kelas eksperimen dan kelas kontrol diatas maka dapat dijelaskan bahwa anak kelas eksperimen memiliki nilai terendah ke nilai tertinggi, nilai rata-rata yang lebih tinggi dibandingkan kelas kontrol. Hal ini menunjukkan bahwa kemampuan kognitif anak kelas eksperimen lebih baik dibandingkan kelas kontrol. Kemampuan kognitif anak kelas eksperimen lebih baik dibanding anak kelas kontrol dimana perkembangan tersebut dipengaruhi oleh penggunaan permainan congklak.

\section{PEMBAHASAN}

Setelah dilakukan perlakuan yang berbeda diperoleh rata-rata skor kemampuan kognitif anak kelas ekperimen 6,25 dan kelas kontrol 4,37. dari hasil observasi kedua sampel diperoleh selisih 1,88. Dari data yang diperoleh tersebut didapat perbedaan yang signifikan antara kemampuan berbicara anak dikelas ekperimen dan kelas kontrol.

Hasil penggunaan permainan congklak pada kelas yang dicobakan, ternyata cukup memuaskan. Hal ini terlihat lebih meningkatnya kemampuan kognitif anak dikelas eksperimen dibandingkan kelas kontrol. Hal ini disebabkan karena pennggunaan permainan congklak yang digunakan guru dalam meningkatkan kemampuan kognitif anak menarik bagi anak sehingga anak bisa menghitung permulaan biji-biji congklak tersebut. Dengan adanya permainan congklak ini anak-anak terlibat dan ikut mengambil bagian secara langsung dan akan lebih mudah bagi anak untuk berhitung permulaan.

Dengan demikian, dalam penelitian ini permainan congklak berpengaruh terhadap kemampuan kognitif anak dimana dengan penggunaan permainan congklak membuat anak lebih bersemangat dan melatih anak untuk berhitung permulaan

\section{SIMPULAN}

Berdasarkan hasil penelitan dan pengolahan data pada sub bab sebelumnya maka dapat diambil kesimpulan, yaitu :

1) Hasil observasi kemampuan kognitif anak kelas eksperimen memiliki rata-rata 6,25 lebih besar dibandingkan kelas kontrol yang memiliki rata-rata 4,37 sehingga dapat disimpulkan bahwa ada pengaruh penggunaan permainan congklak terhadap kemampuan kognitif anak. Menurut Subagiyo (dalam Mulyani 2016:51)menyatakan bahwa manfaat permainan tradisional yaitu, mengembangkan kecerdasan logika anak, beberapa permainan tradisional melatih anak untuk berhitung dan menentukan langkah-langkah yang harus dilewati. Misalnya engklek, congklak lompat tali,encrak,bola bekel, dan lain-lain. Kegiatan 
yang dapat mengembangkan kemampuan kognitif anak (menghitung permulaan) salah satu dengan permainan congklak.

2) Hasil uji hipotesis terbukti bahwa $t_{\text {hitung }}(0,8065)>t_{\text {tabel }}(0,220)$. hal tersebut sesuai dengan hasil uji hipotesis $\mathrm{H}_{\mathrm{O}}$ ditolak dan $\mathrm{H}_{\mathrm{a}}$ diterima. Sehingga dapat dinyatakan ada pengaruh yang signifikan antara permainan congklak terhadap kemampuan kognitif anak usia 4-5 tahun di TK AN NUR

Berdasarkan pembahasan dan kesimpulan yang telah dikemukakan diatas maka peneliti memberikan beberapa saran sebagai berikut :

1) sebaiknya guru sering menggunakan permainan congklak dalam pembelajaran dan mengikutsertakan semua anak terlibat dalam pembelajaran sehingga setiap anak dapat mengembangkan kemampuan kognitif.

2) hendaknya lembaga sekolah bekerjasama dengan para guru untuk melengkapi sarana dan prasarana dalam hal media pembelajaran sehingga pembelajaran dalam upaya meningkatkan kemampuan kognitif anak dapat terlaksana

3) Sebaiknya peneliti selanjutnya lebih memperluas dan memperbanyak bahan kajian yang hendak diteliti dengan menggunakan permainan pada anak

\section{DAFTAR RUJUKAN}

Beaty, Janice J. 2013. Observasi Perkembangan Anak Usia Dini. Jakarta: Kencana

Dewi, Rosmala. 2005. Berbagai Masalah Anak Taman Kanak-Kanak. Jakarta: Departemen Pendidikan Nasional, Direktorat Jenderal Pendidikan Tinggi, Direktorat Pembinaan Tenaga Pendidikan Dan Ketengaan Perguruan Tinggi

Khadijah. 2016. Perkembangan Kognitif Anak Usia Dini. Medan

Khadijah. 2012. Konsep Dasar Pendidikan Prasekolah. Bandung: Citapustaka Media Perintis

Khadijah dan Armanilah. 2017. Bermain Dan Permainan Anak Usia Dini. Medan:Perdana publishing

Mulyani, Novi. 2016. Super Asyik Permainan Tradisional Anak Indonesia. Yogyakarta: Diva press

Rolina, Nelva. 2012. Alat Permainan Edukatif. Yogyakarta : ombak

Sugiyono. 2011. Statistika untuk penelitian. Bandung : Afabeta

Sugiyono. 2015.Metode Penelitian Pendidikan. Bandung : Afabeta

Sujiono.Yuliani Nuraini. 2009. Konsep Dasar Pendidikan Anak Usia Dini. Jakarta: Indeks

Susanto, Ahmad. 2011. Perkembangan Anak Usia Dini. Jakarta: kencana

Suyadi. 2010. Psikologi Belajar Pendidikan Anak Usia Dini. Yogyakarta:pedagogia 